\author{
換気量既知の試験住宅を用いた多種トレーサーガス法の検証 \\ EVALUATION OF THE MULTIPLE TRACER GAS TECHNIQUE IN \\ AN ACTUAL-SIZED TEST HOUSE WITH KNOWN AIRFLOW RATES
}

\author{
絵内正道*, 澤地孝男**, 島田 潔***, 福島史幸***, 瀬戸裕 直 $* * * *$ \\ Masamichi ENAI, Takao SAWACHI, Kiyoshi SHIMADA, \\ Fumiyuki FUKUSHIMA and Hironao SETO
}

\begin{abstract}
The interzonal airflow rates in an actual-sized test house were measured by using the multiple tracer gas technique. Cylinders were installed within the walls of the test house so that the volume of infiltrated and exfiltrated air-leakage could be varied.

1. The values obtained by the multiple tracer gas technique had errors of $20 \%$ to $30 \%$, but the degrees of accuracy in the case of 4-zone model and 5-zone model were similar to those for a 2-zone model and 3-zone shown in previous reports.

2. When the degree of airtightness was low (e.g., $\left.5 \mathrm{~cm}^{2} / \mathrm{m}^{2}\right)$, the calculated airflows were less than those in other tests.

3. The calculated results are almost equal between 4-zone model and 5-zone model even if the volume of the interconnected space, such as stairs, is not considered in the calculation of airflow rates between zones.
\end{abstract}

Keywords: multiple tracer gas technique, modeling, interzonal airflows, multi-zone model, pressure difference 多種トレーサーガス法, モデリング, 室間換気量, 多数室モデル, 差圧

1.はじめに（研究の背景と目的）

単一ガスによる多数室換気の測定はこれまでも数多く行われてき た1221。また, 多種トレーサーガス法においても 2 室〜 3 室モデ ルを対象に，ガスの放出方法，妥当な算定時刻，モデリング，算定 式などの基礎的な検討が行われてきたが3141，実験室実験を除き， 換気量既知の実家屋を対象に厳密な精度検証がその都度行扎てき た訳ではない。トレーサーが 4 種ガスに広がった現時点で従前の知 見を踏まえながら，内外差圧測定装置等が付設された実験住宅を用 いて多種トレーサーガス法の精度的な検証を行うことは, 今後の測 定結果の拠所となるに違いない。また, 高気密化住宅の普及が著し い北海道にあって，パッシブ換気も有用な空気環境計画手法の一つ であると考えられる様になってきた。

本論文の目的は，それらを踏まえ，換気量既知の試験住宅を用い て, (1)各居室の換気量と換気経路の実体把握を可能にする多種卜 レーサーガス法の精度的な検証を行い, 測定結果の妥当性を把握す ることと, (2) 4 室を超えた空間を実体容積なしの換気連絡路と仮想 した室間換気量測定の可能性の有無を検討することにある。

\section{2. 実測の概要}

2-1多種トレーサーガス法

多種トレーサーガス法では, 複数の測定対象空間で複数のガス濃 度が同時刻的に得られた場合, 内外温度差や風速等の換気動力が時 間的に変動しても室間換気量や各室外気流入分配率を変動現象とし て解析可能と考えられている。しかし, 対象室毎のガス濃度収支を
基本としたトレーサーガス法の場合, 各測定対象室毎の瞬時一様拡 散が大前提であり, 従前から妥当なガス濃度の測定と算定に関わっ て推定精度の検討を行ってきた5〉。それ故，如何に瞬時一様拡散が大 前提であっても, 強力な拡散混合ファンを使用することは, 温度差 による室間換気の奏情を阻害する要因となるので, 避けることが望 ましいタ⿱。本論文では, 混合ファンを使用せず, ガス放出口での拡散 小ファンのみを用い, 対象空間の環境特性に応じた室間換気量と換 気経路を検討した。

\section{2-2 シリンダーハウス}

建設省・建築研究所の人工気象室 (室規模 : 間口 $12 \cdot$ 奥行 $13 \cdot$ 室 高 $9[\mathrm{~m}]$, 外気導入量 : $\left.400\left[\mathrm{~m}^{3} / \mathrm{min}\right]\right)$ 内に建設された実大試験住 宅の平面をFig. 1 に示す。2 階建て住宅・延床面積約 $66\left[\mathrm{~m}^{2}\right]$ で, その 最大の特徵は, 外界の温度変動や風速変動の影響を全く受けないこ と，任意に内外温度差の設定ができること，Fig. 2 に示寸内径 50 $[\mathrm{mm}]$ 長さ $375[\mathrm{~mm}]$ の直管のノーマルシリンダー及びその直管の中 にスリット状の細片を組み込んだスリットシリンダーの開・閉に よって, 外界と室間の隙間の配置とその面積(気密性能) を任意に 設定できること, 各シリンダーの内外差圧から通過風量（換気量） を計測できる゙"ことにある。それ故，同試験住宅は”シリンダー八 ウス”とも呼称されている。

\section{$2-3$ 実測条件の設定}

実測の主目的が多種トレーサーガス法の精度検定にあるため，4
* 北海道大学大学院工学研究科 教授. 工博

** 建設省建築研究所 室長・I博

*** 北海道大学大学院工学研究科 大学院生

**** 建設省建築研究所 主任研究員
Prof., Graduate School of Engineering, Hokkaido University, Dr. Eng. Building Research Institute, Ministry of Construction, Dr. Eng.

Graduate School of Engineering, Hokkaido University Building Research Institute, Ministry of Construction 

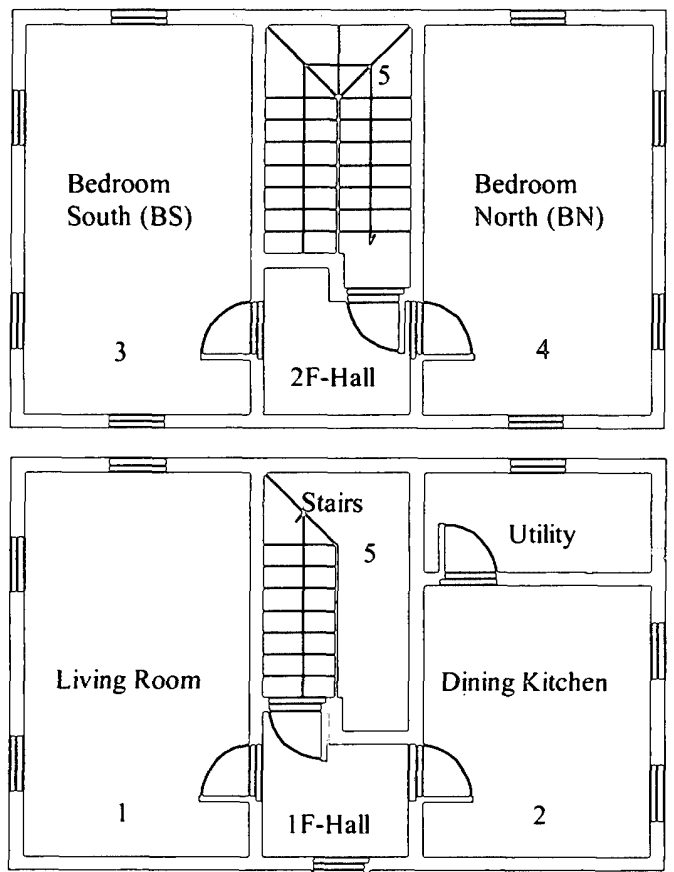

Thickness of foam Low-e pair glass polystyrene: $100[\mathrm{~mm}]$

\begin{tabular}{|c|c|c|c|c|c|}
\hline Room & LV & DK & BS & BN & SC \\
\hline Volume $\left[\mathrm{m}^{3}\right]$ & 31.67 & 31.67 & 31.67 & 31.67 & 49.36 \\
\hline
\end{tabular}

Fig. 1 Floor plans of test house called Cylinder House

室や 5 室のモデル化が容易な様に, DK とUtilityの間のドアを開 放し，両空間を併せて 1 室化した。壁隙間の開口は $2 \mathrm{~F}$ 最上と $1 \mathrm{~F}$ 最下位置を開放し $(\mathrm{h}=6040[\mathrm{~mm}])$ ，基本的に北海道の独立住宅の使 用状況と気密性能水隻を想定した。また, 差圧い" は圧力差変動 を 10 秒間隔で測定し，4分間の平均值からシリンダー通過風量（換 気量）に換算した。隙間開口はノーマルシリンダーのみで模擬を 行った。その設定条件をTable 1 に示す。

換気方式：(1)内外温度差を動力とする自然換気 (2) $1 \mathrm{~F} \cdot \mathrm{DK}$ から排気する機棫換気 の 2 種。

内外温度差 : 試験住宅の室温を一律 $25\left[{ }^{\circ} \mathrm{C}\right]$ に設定（㷫負荷に応じ， 1, 2 台の赤外線暖房機(出力 $1[\mathrm{~kW}])$ を外壁から $1 \mathrm{~m}$ 離して中央に向け設圈)

(1)人工気象室温 $-5\left[{ }^{\circ} \mathrm{C}\right]$ の時の $30[\mathrm{deg}]$

(2) 同室温 $15\left[{ }^{\circ} \mathrm{C}\right]$ の時の $10[\mathrm{deg}]$ の 2 種。

気密性能: (1)床面椯当りの相当開口面積 $1\left[\mathrm{~cm}^{2} / \mathrm{m}^{2}\right]$

$$
\text { (2) } \left.5\left[\mathrm{~cm}^{2} / \mathrm{m}^{2}\right] \quad 0\right) 2 \text { 種。 }
$$

生活条件：(1)内部ドア開

$$
\text { (2) ドア閉 の2 種。 }
$$

（注）室閒ドアのアンダーカットは内径 $160[\mathrm{~mm}]$ の円形開口（有 効開口面穦 $163 \mathrm{~cm}^{2}$ ) で模擬し, 室内温度の制御はサーモスタット の on-off で行ったが，变動幅は土0. $3^{\circ} \mathrm{C}$ 以内に納まり，定常状態 は十分に確保されている。また，実験住宅の外壁は発泡ポリスチ レン $100[\mathrm{~mm}]$, Low-eペアガラスで断熱されているため, 居室
の温度むらは内外温度差 $30 \mathrm{deg}$ の場合でその 1 割末満である。

\section{2-4 測定システム}

トレーサーガスとして， $\mathrm{H}_{4}, \mathrm{~N}_{2} 0, \mathrm{SF}_{6}, \mathrm{HFC134a}$ の 4 稙を用い た。上記 4 種ガスを各 1 福毎にBN，BS，LV，DKへマスフロー コントローラー (1\%FS) を介して一定 $\left(0.003\left[\mathrm{~m}^{3} / \mathrm{h}\right]\right)$ 供給し, 室の 中央・ $1 / 2$ 高さのガス放出口では, 放出口位置に取り付けた小ファ ン $(\mathrm{AC} 100 \mathrm{~V} / 14 \mathrm{~W} \phi: 110[\mathrm{~mm}])$ のみを用いて混合拡散の促進を図っ て、る。なお, 階段室では, 4 種ガスの供給停止後, ガス渡度が 十分に希釈・堿少したのを確認し，4種ガスの一つを一定供給し， その激度変動を 5 種目のガス浱度変動情報と考えた。

ガス浔度の测定は, 室の $1 / 2$ 高さの位置で各壁面近傍に 2 管。計 8 管を 1 点に集約, 各測定対象室毎に 1 点で 4 点, 階段室の上下で 2 点, 人工気象室内 (外気相当) の 2 点, 計 8 点で行なった。1測定 点につき8本の接続端子を有するセルに管長を等しくしたビニール チューブを装着し（Manifold Sampling），各測定対象空間の容穦 平均搌度が得られるよう工夫した。全計測点毎の総管長を等しくし たガスサンプリング系は常時吸引とし，タイムラグの影淛の㪕减化 に配虑した。2 台のガスセレクターを 5 分間隔 $\times 4$ チャンネル (測 定間隔 20 [分] ) に設定・操作し，ガスクロマトグラフ [P200 Micro GC: HP/ 標準ガス $(1 \% \mathrm{FS})]$ を用いて経時的なガス搌度変動の 分析を行なった。測定システムをFig. 3 に示す。

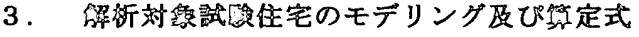

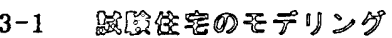

試験住宅のモデル化に際し，Fig. 3に示すLVが室1，DKが室2, BS が室 3，BNが室 4，SCが室 5 に対応している。Fig. 3 に示す 試験住宅は 5 室モデル相当と言える。しかし, トレーサーガスが 4 種に限られているので, 実際に生じているであるう階段室のガス搌 度むらや，階段室を介すことでガス搪散移動に必要となるであろう 時間遅れを無視して, Fig. 4-1に示す様な 4 種ガス・4室モデルへ の簡略化を試みた。これは実体容穦を持たない換気の連絡路として 階段室を仮想したモデリングと言える。搌度測定に際して階段室の 上下 2 カ所で 4 種ガス泿度を計測しているが, 室間換気量の算定に 階段室のガス搌度を用いていない。

Fig. 4-2 は， 2 回に分けてガス放出を行い，階段室を含めた 5 室でトレーサーガスを供給しているので，5種ガス・5 室モデルの モデリングとなる。

\section{3-2 算定式}

室 1 を例に，4室モデルと 5 室モデルにおける換気量収支式とト レーサーガス (i) の浱度常微分方程式を表示すると次の様になる。 4 室モデル：

室 1 の換気量収支式：

$\mathrm{F}_{01}+\mathrm{F}_{21}+\mathrm{F}_{31}+\mathrm{F}_{11}-\left(\mathrm{F}_{10}+\mathrm{F}_{12}+\mathrm{F}_{13}+\mathrm{F}_{14}\right)=0$

室 1 のトレーサーガス (i) 搌度收支式 :

$\mathrm{C}_{0 i} \cdot \mathrm{F}_{01}+\mathrm{C}_{2 i} \cdot \mathrm{F}_{21}+\mathrm{C}_{3 i} \cdot \mathrm{F}_{31}+\mathrm{C}_{4 i} \cdot \mathrm{F}_{11}-\mathrm{C}_{1 i} \cdot\left(\mathrm{F}_{10}+\mathrm{F}_{12}+\mathrm{F}_{13}+\mathrm{F}_{14}\right)$ $=V_{1} \cdot d_{C} i \mathrm{i} / \mathrm{dt}-\mathrm{M}$

Table 1 Measurement conditions

\begin{tabular}{|c|c|c|c|c|c|}
\hline Test & Ventilation method & Temperature difference & Air tightness $\left[\mathrm{cm}^{2} / \mathrm{m}^{2}\right]$ & Door condition & Undercut of doors \\
\hline 1 & Natural ventilation & $30^{\circ} \mathrm{C}$ & 1 & close & $160 \phi$ \\
\hline 2 & Natural ventilation & $30^{\circ} \mathrm{C}$ & 1 & open & \\
\hline 3 & Mechanical ventilation & $30^{\circ} \mathrm{C}$ & 1 & close & $160 \phi$ \\
\hline 4 & Mechanical ventilation & $30^{\circ} \mathrm{C}$ & 1 & open & \\
\hline 5 & Natural ventilation & $30^{\circ} \mathrm{C}$ & 5 & close & $160 \phi$ \\
\hline 6 & Natural ventilation & $10^{\circ} \mathrm{C}$ & 1 & close & $160 \phi$ \\
\hline
\end{tabular}




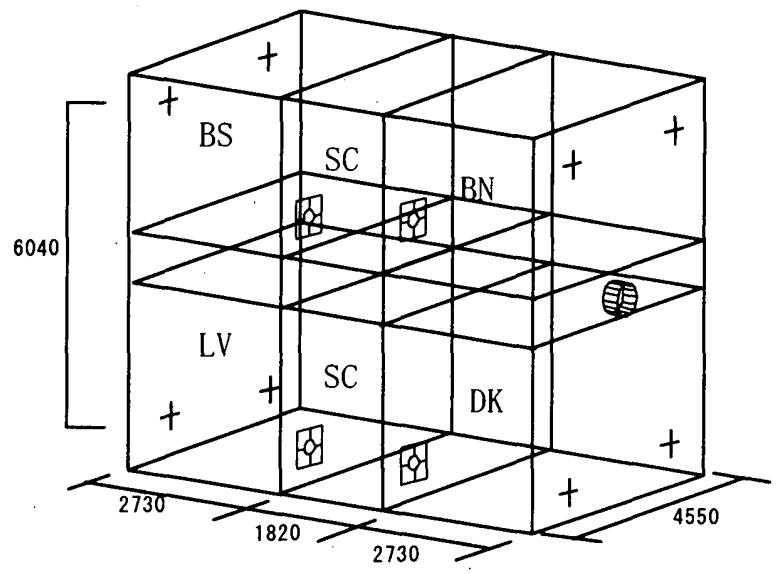

+ Cylinder

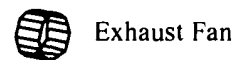

[1] Cylinder on Partitions as the undercut of doors

Fig. 2 Location of Cylinders

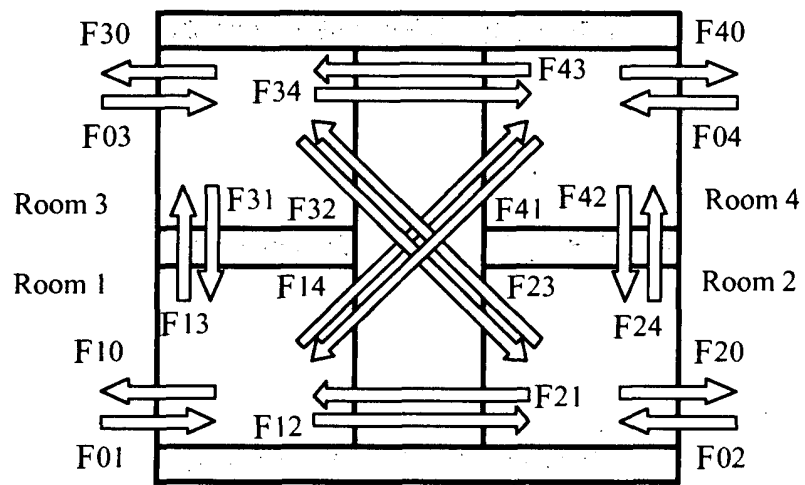

Fig. 4-1 4-zone model

5 室モデル：

室 1 の換気量収支式：

$F_{01}+F_{51}-\left(F_{10}+F_{15}\right)=0$

室 1 のトレーサーガス (i)の濃度収支式 :

$\mathrm{C}_{0 i} \cdot \mathrm{F}_{01}+\mathrm{C}_{5 i} \cdot \mathrm{F}_{51}-\mathrm{C}_{11} \cdot\left(\mathrm{F}_{10}+\mathrm{F}_{15}\right)=\mathrm{V}_{1} \cdot \mathrm{dC}_{11} / \mathrm{dt}-\mathrm{Mi}$ ただし，

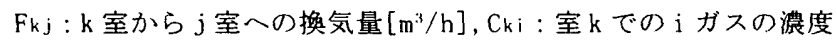
$\left[\mathrm{m}^{3} / \mathrm{m}^{3}\right], V_{1}$ : 室 1 の室容積 $\left[\mathrm{m}^{3}\right], M_{i}: \mathrm{i}$ ガスの発生量 $\left[\mathrm{m}^{3} / \mathrm{h}\right]$

20 分毎のガス濃度測定データを用いて室間換気量を未知数とす る室 2 室 5 の換気量収支と各ガス収支の連立式を立てた。4 室 モデルで室数 $\mathrm{n}=4$ とすると，一般にガス濃度と換気量の収支式の 数は $\mathrm{n}(\mathrm{n}+1)=20$ となるが, 換気の経路によっては, 20 未満の式数 で室閒換気量の解を求めることができる。ガス濃度の測定結果を Fig. 5〜Fig. 10 に示す。到達濃度の様子から, 内外温度差が 小さいTest 6 は到達濃度が高くなるので換気量が少ないことや, 機械換気を行ったTest 3 , Test 4 や気密性能が低いTest 5 は 到達濃度が低いので換気量の多いことが理解されるし，また，あ る室のガス濃度が極端に低濃度かあるいはゼ口になっている場合 には，それは外気が多量に流入してそのガスの濃度が希釈された か，あるいはその室にそのガスを放出した室の空気が全く流入し ていない状況にあることを意味している。濃度履歴から判断して, 相互関係の希薄な室間換気成分を予め除去したモデリングを工夫

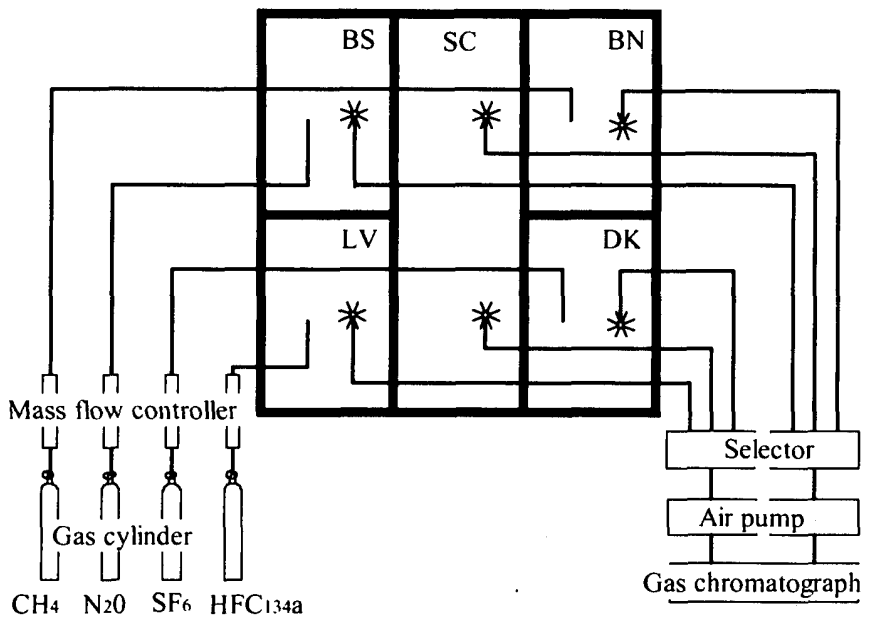

Fig. 3 Measurement system

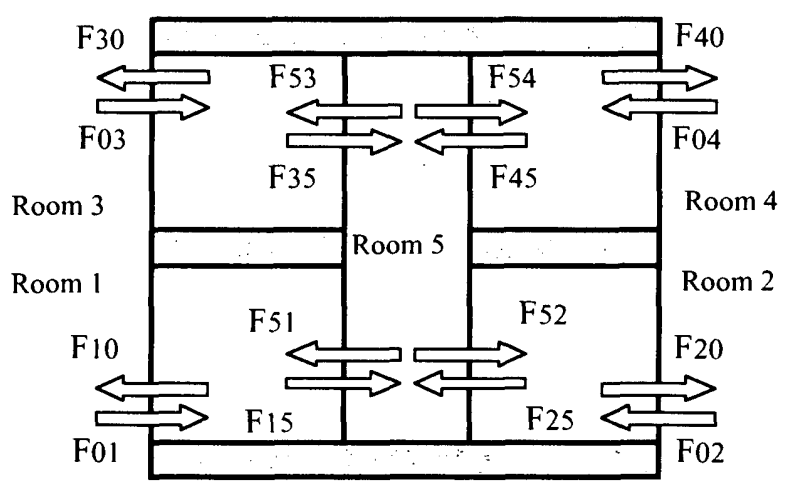

Fig. 4-2 5-zone model

した。省略可能と思われる換気成分 $\mathrm{F}_{\mathrm{k}, \mathrm{j}}$ を残したまま推定作業を進 めることは，ルーティン的な作業にはなるが，換気量の算定精度 の向上に直結する訳ではない。そこで実測では，Fig. 4-1に示 す 4 室モデルの室間換気量 20 成分を $8 \sim 12$ 成分に, また Fig. 42 に示す 5 室モデルの室間換気量 16 成分を $8 \sim 12$ 成分とする収支 式を工夫した。収支式が未知数を上回る場合には，それらを省略 することなく並立させ，最小二乗法による整式を行った連立方程 式にガウス消去法を用いて解を求め，換気量を算定した。

4.トレーサーガス法と差圧法による测定結果の比較 Fig. 7 12 に経時的な換気量の算定結果を示す。定常の条件設 定にも関わらず，温度差換気では，内外温度差が $10[\mathrm{deg}]$ の Test

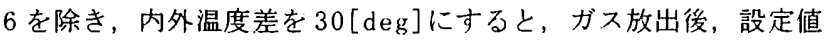
(シリンダー差圧から推定した通過風量の測定值, Table 2 の上 段参照) に達するに必要な時間が, Test 5, Test 2, Test 1 の 順に增大している。また，機械換気の Test 3，4 は放出直後から 設定值に近づいている。この理由として，(1)換気量の少ない[Test 6]は, 泠外気が流入してもその流入層は薄くて, 拡散され易い。 実容積に対する影響も軽微で, 多点サンプリングは一様拡散に近 いガス濃度を捉えている。(2)換気量の增加で[Test 2, 1]，流入 の経路がより明確になって, 主流域が形成されるようになると, 放出直後の一様拡散は難しい。多点サンプリングが高濃度域側に あると換気量を低めに（低濃度域側にあると換気量を高めに）算 
Test 1

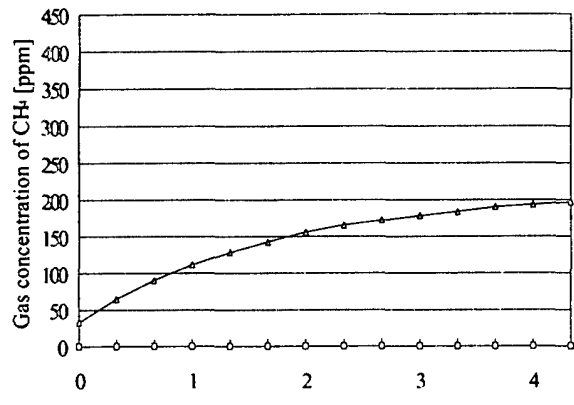

Elapsed time[h]

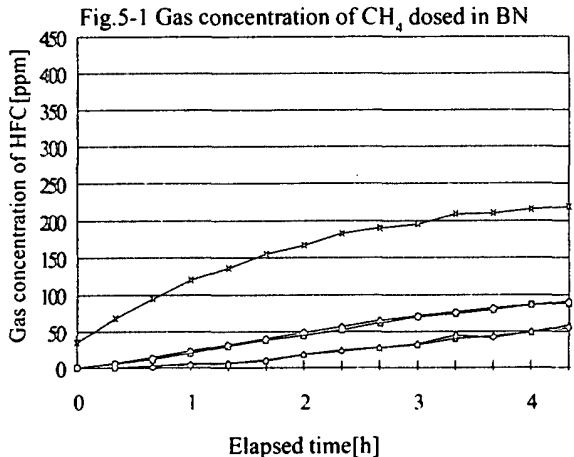

Fig.5-2 Gas concentration of HFC dosed in LV

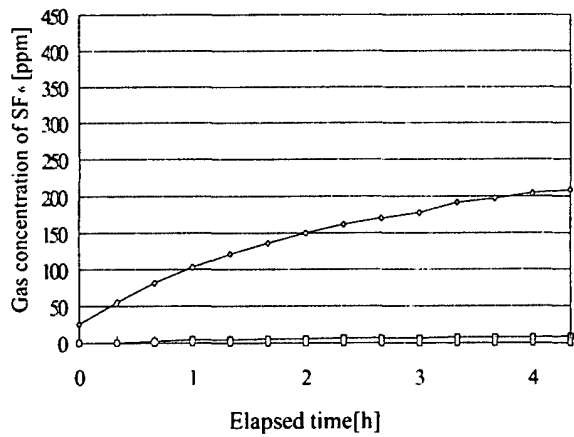

Fig.5-3 Gas concentration of $\mathrm{SF}_{6}$ dosed in BS

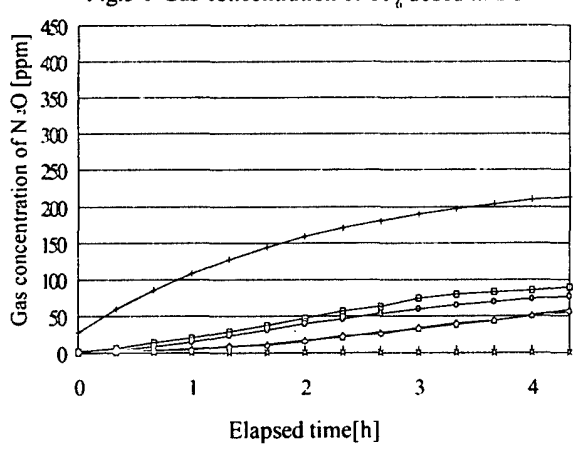

Fig.5-4 Gas concentration of $\mathrm{N}_{2} \mathrm{O}$ dosed in DK

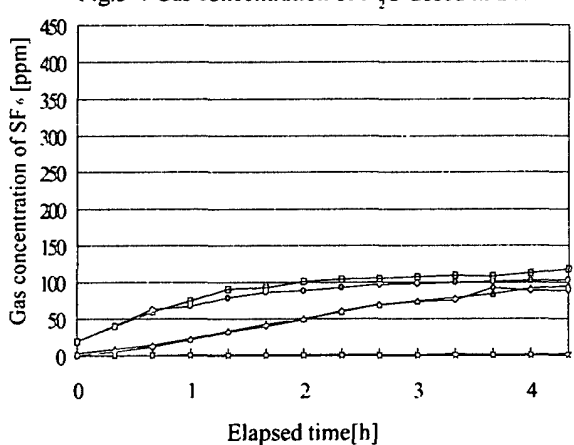

Fig.5-5 Gas concentration of $\mathrm{SF}_{6}$ dosed in $\mathrm{SC}\left(5-\right.$ zonc model) Fig.6-5 Gas concentration of $\mathrm{SF}_{6}$ dosed in SC(5-zonc model) Fig.7-5 Gas concentration of $\mathrm{N}_{2} \mathrm{O}$ dosed in $\mathrm{SC}$ (5-zone model)
Test 2

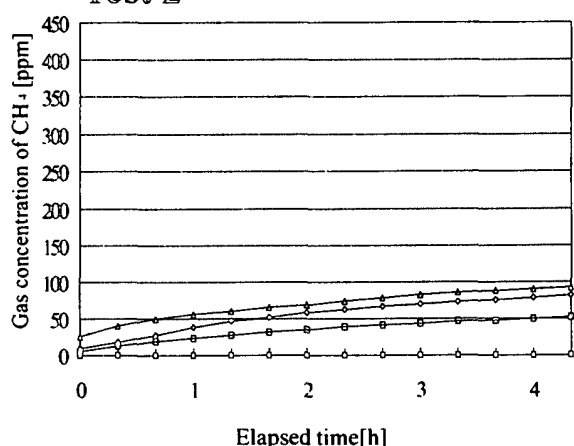

Fig.6-1 Gas concentration of $\mathrm{CH}_{4}$ dosed in $\mathrm{BN}$

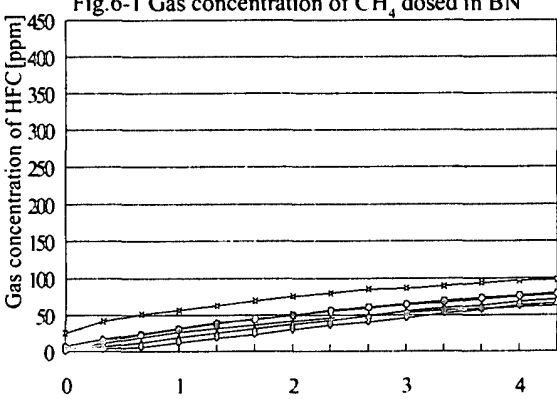

Elapsed time[h]

Fig.6-2 Gas concentration of HFC dosed in LV

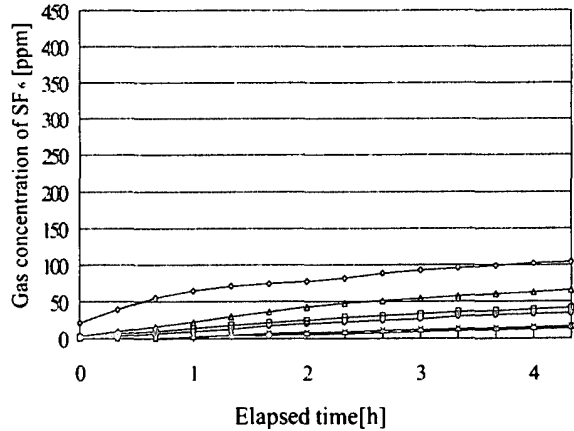

Fig.6-3 Gas concentration of SF dosed in BS

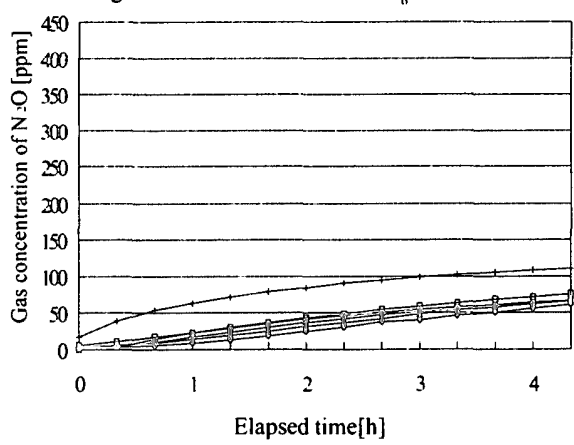

Fig.6-4 Gas concentration of $\mathrm{N}, \mathrm{O}$ dosed in DK

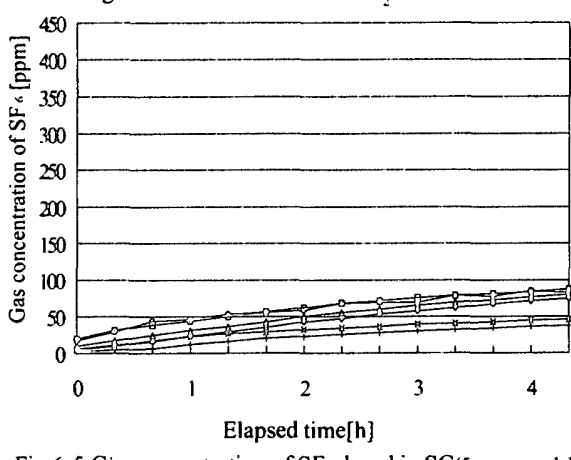

Test 3

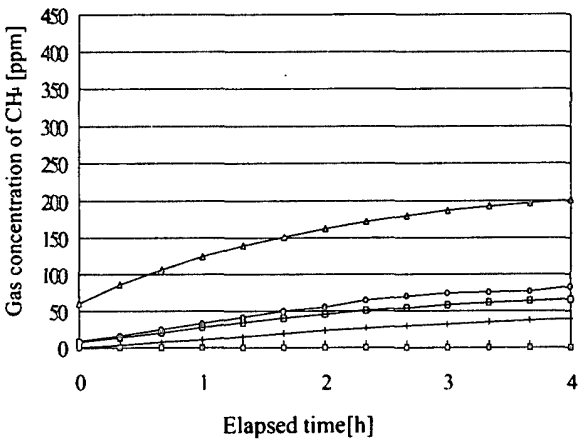

Fig. 7-1 Gas concentration of $\mathrm{CH}_{4}$ dosed in $\mathrm{BN}$

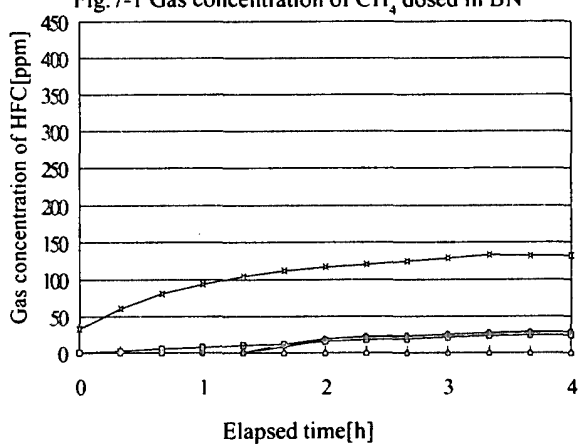

Fig. 7-2 Gas concentration of HFC dosed in LV

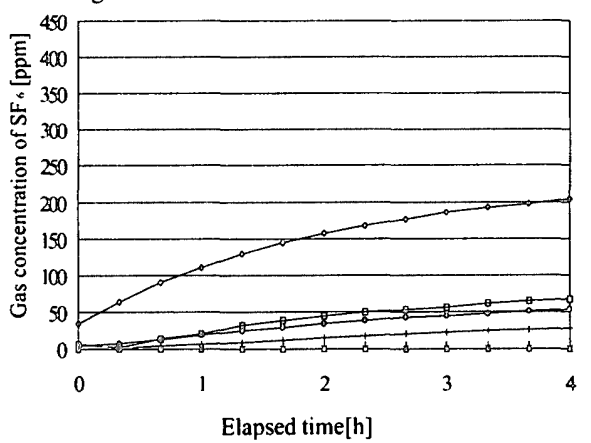

Fig. 7-3 Gas concentration of $\mathrm{SF}_{6}$ dosed in BS

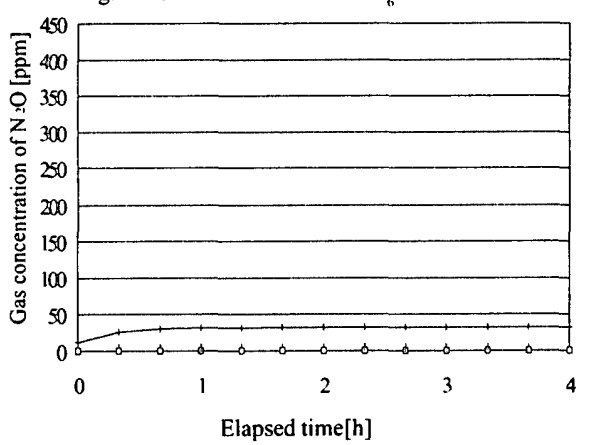

Fig. 7-4 Gas concentration of $\mathrm{N}_{2} \mathrm{O}$ dosed in $\mathrm{DK}$

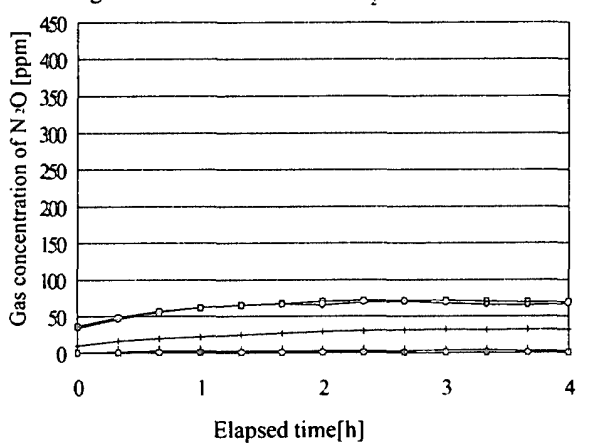

$$
\rightarrow \mathrm{BS} \quad \rightarrow \mathrm{SC}(2 \mathrm{~F}) \quad \rightarrow \mathrm{BN} \quad \rightarrow \mathrm{LV} \quad \rightarrow \mathrm{SC}(1 \mathrm{~F}) \quad+\mathrm{DK}
$$


Test 4

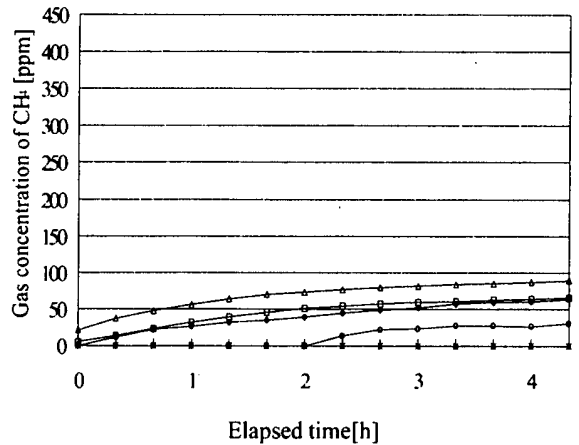

Fig.8-1 Gas concentration of $\mathrm{CH}_{4}$ dosed in $\mathrm{BN}$

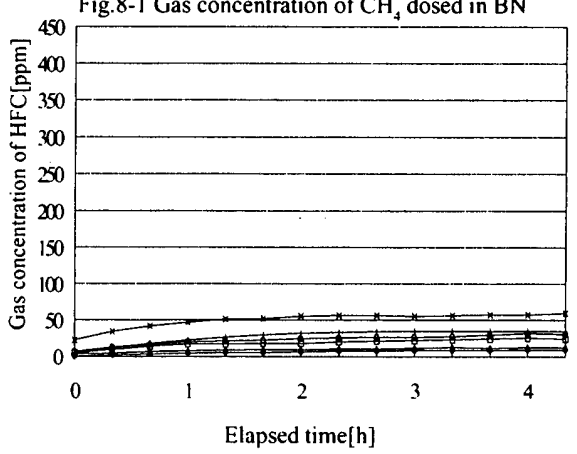

Fig.8-2 Gas concentration of HFC dosed in LV

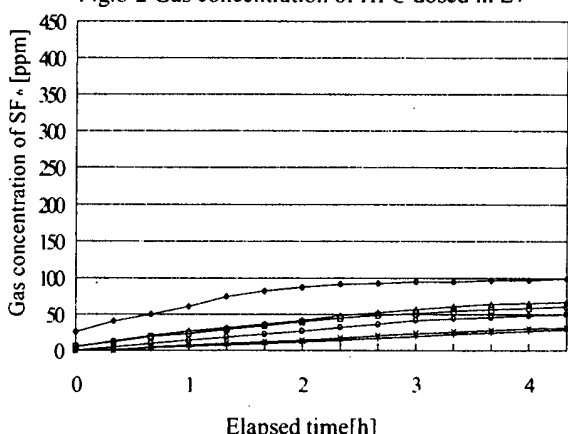

Fig.8-3 Gas concentration of $\mathrm{SF}_{6}$ dosed in $\mathrm{BS}$

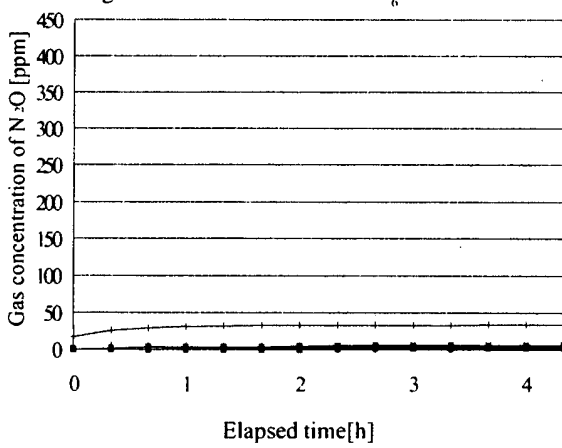

Fig. 8-4 Gas concentration of $\mathrm{N}, \mathrm{O}$ dosed in DK

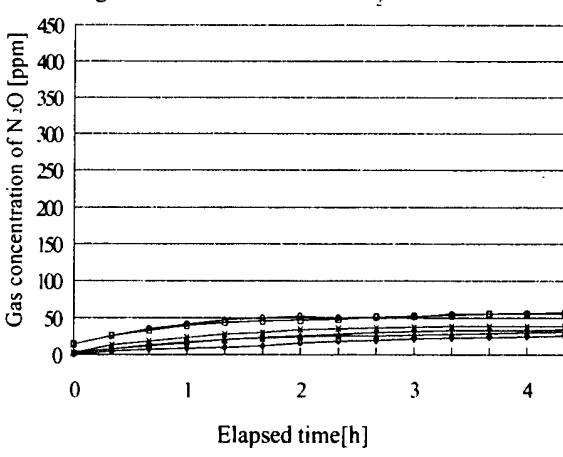

Test 5

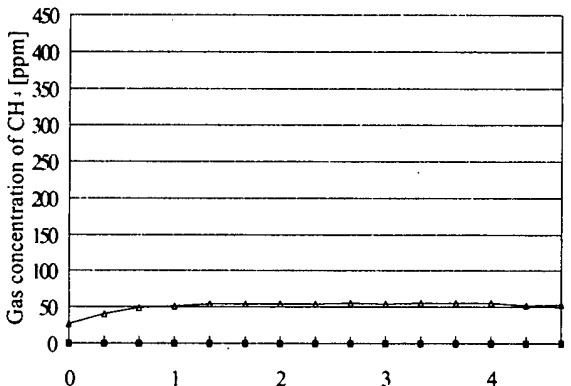

Elapsed time[h]

Fig.9-1 Gas concentration of $\mathrm{CH}_{4}$ dosed in $\mathrm{BN}$

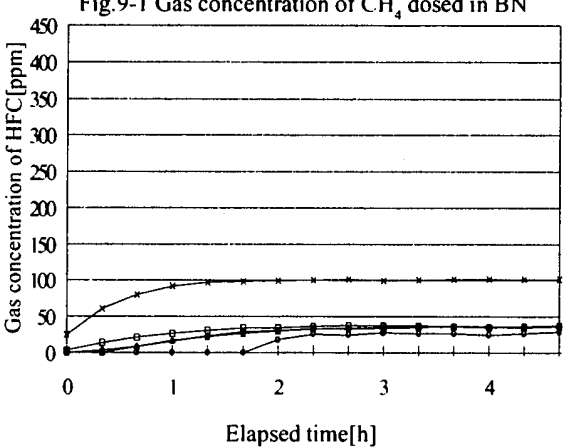

Fig.9-2 Gas concentration of HFC dosed in LV

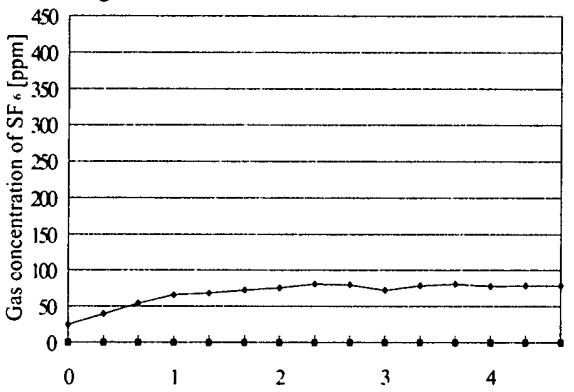

Elapsed time[h]

Fig.9-3 Gas concentration of $\mathrm{SF}_{6}$ dosed in BS

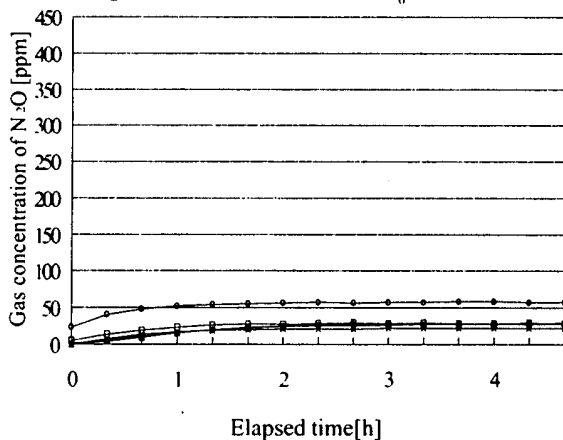

Fig.9-4 Gas concentration of $\mathrm{N}_{2} \mathrm{O}$ dosed in DK

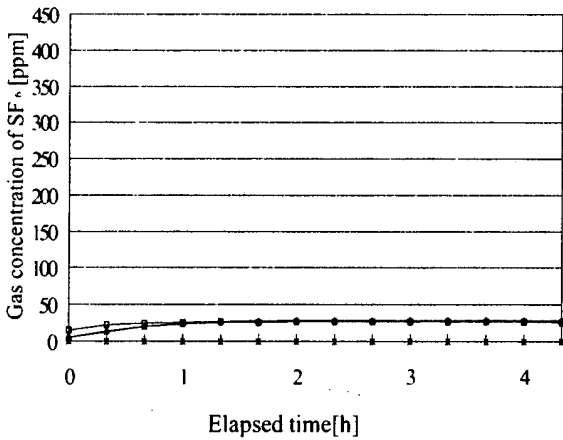

Test 6

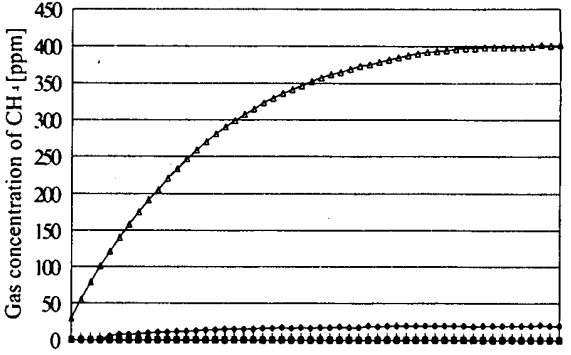

15

Elapsed time[h]

Fig. 10-1 Gas concentration of $\mathrm{CH}_{4}$ dosed in $\mathrm{BN}$

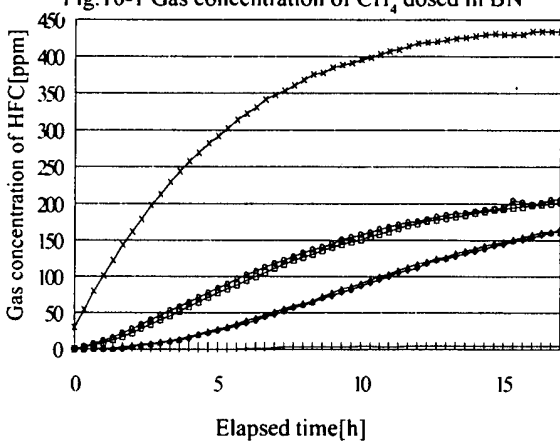

Fig. 10-2 Gas concentration of HFC dosed in LV

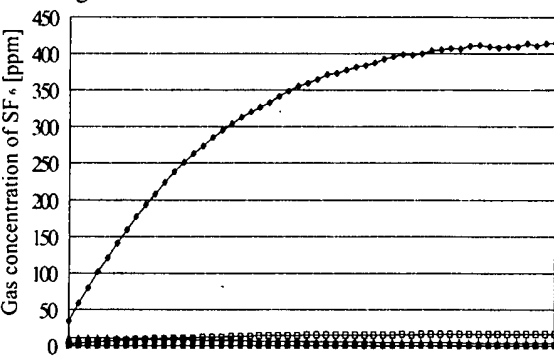

Elapsed time[h]

Fig. 10-3 Gas concentration of $\mathrm{SF}_{6}$ dosed in BS

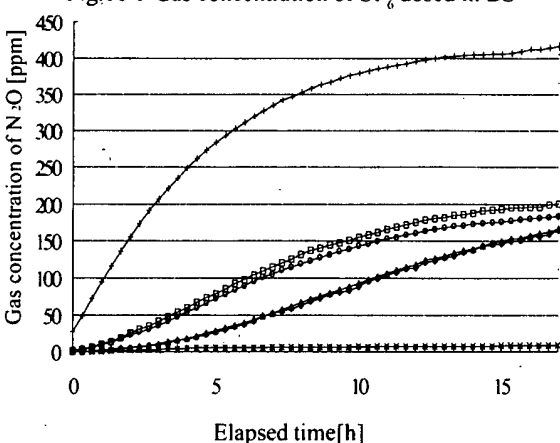

Fig. 10-4 Gas concentration of $\mathrm{N}_{2} \mathrm{O}$ dosed in DK

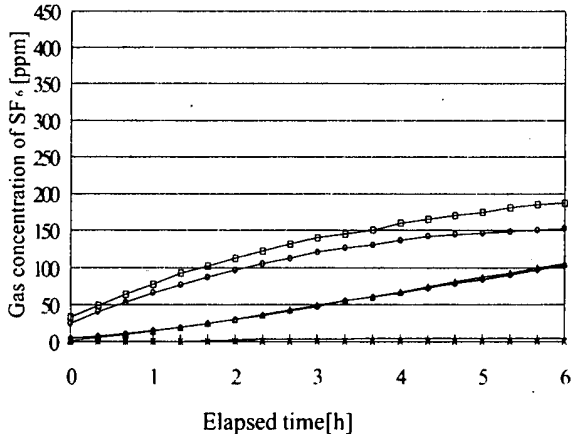

Fig.8-5 Gas concentration of $\mathrm{N}_{2} \mathrm{O}$ dosed in $\mathrm{SC}$ (5-zone model) Fig.9-5 Gas concentration of $\mathrm{SF}_{6}$ dosed in SC(5-zonc model) Fig. 10-5 Gas concentration of SF dosed in SC(5-zone model)

$\rightarrow \mathrm{BS} \rightarrow \mathrm{SC}(2 \mathrm{~F}) \rightarrow \mathrm{BN} \quad * \mathrm{LV} \rightarrow \mathrm{SC}(1 \mathrm{~F})+\mathrm{DK}$




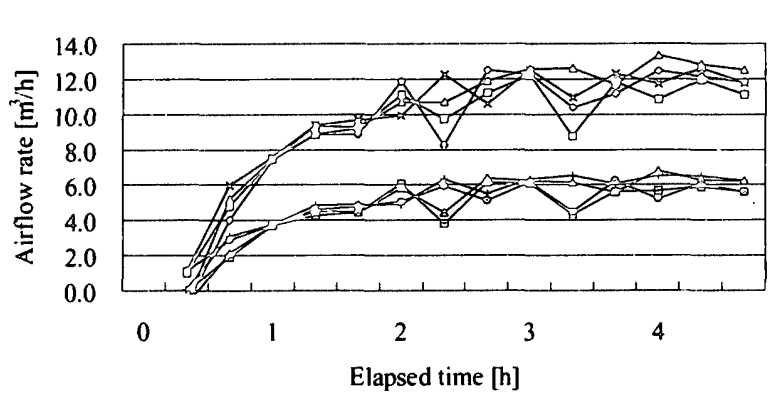

Fig. 7-1 Airflow rates in Test 1 of 4-zone model

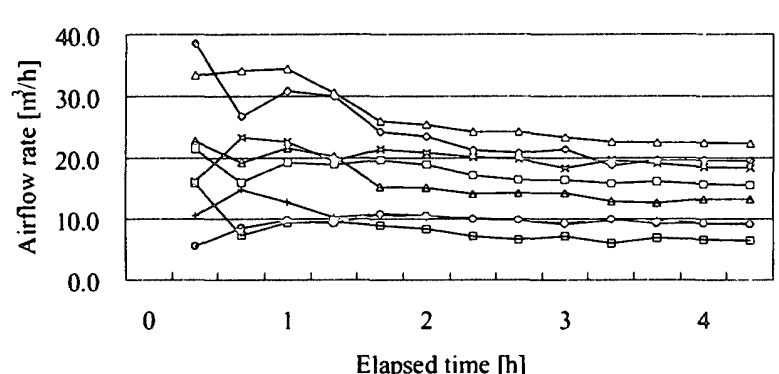

Fig. 8-1 Airflow rates in Test 2 of-4zone model
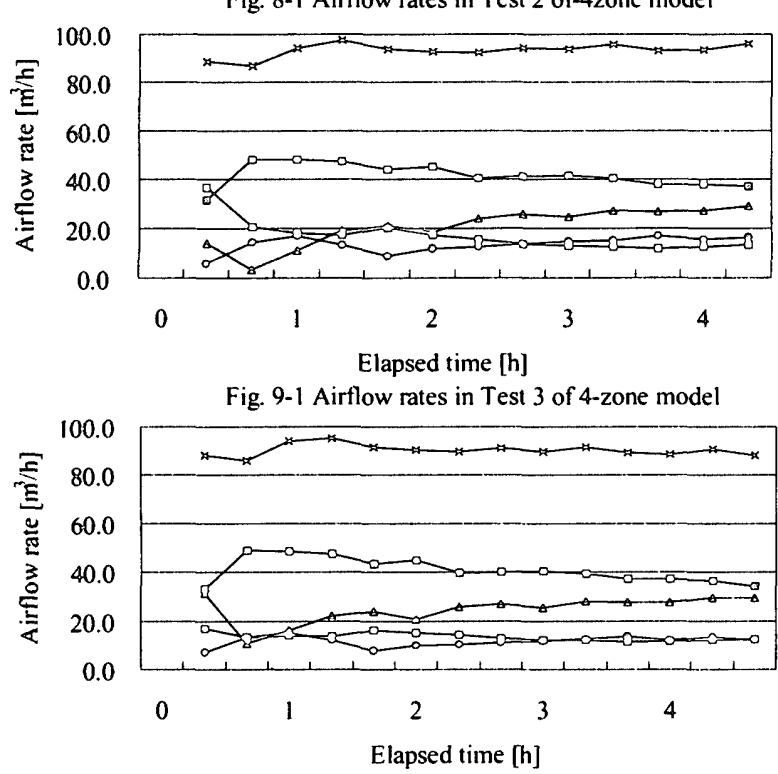

Fig. 10-1 Airflow rates in Test 4 of 4 -zone mode

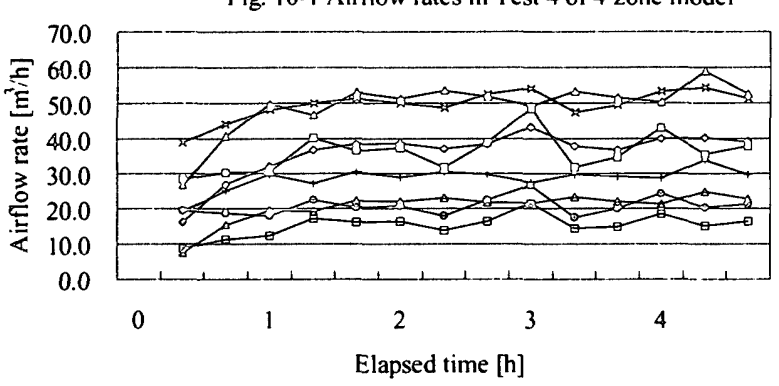

Fig. 11-1 Airflow rates in Test 5 of 4-zone model

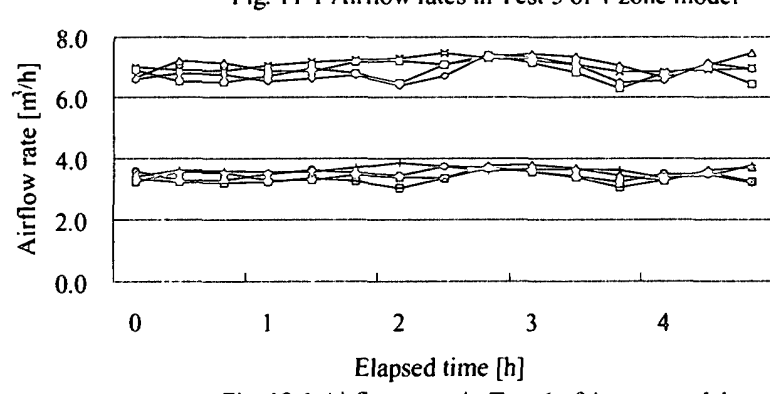

Fig. 12-1 Airflow rates in Test 6 of 4-zone model
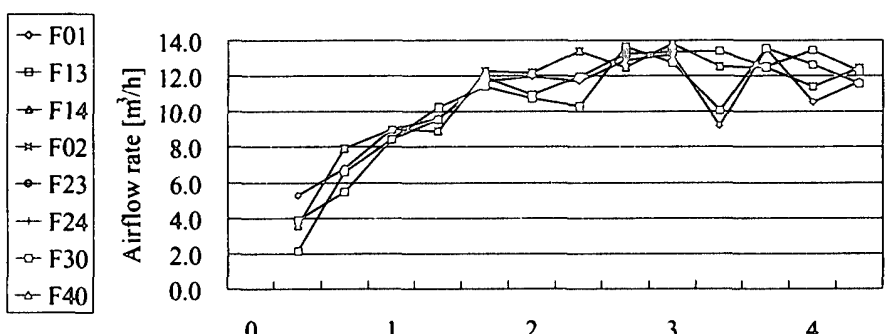

- F15

$\rightarrow \mathrm{F02}$

$\rightarrow$ F 25

$-\mathrm{F} 30$

+ F53

$\rightarrow$ F40

Fig. 7-2 Air flow rates in Test 1 of 5-zone model
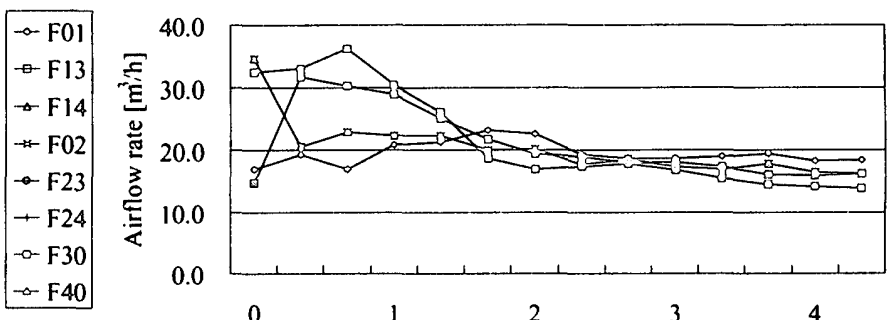

$\rightarrow \mathrm{F01}$

$\rightarrow$ F15

$\triangle \mathrm{F} 02$

$\rightarrow$ F25

$\rightarrow F 30$

$-F 53$
$-F 40$

Fig. 8-2 Air flow rates in Test 2 of 5-zone model
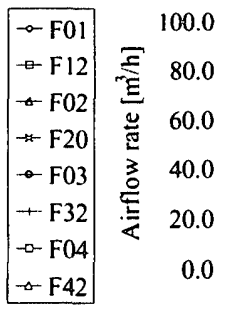

$$
\begin{array}{|}
\hline \\
\hline \\
\hline
\end{array}
$$$$
\begin{aligned}
& \rightarrow F 01 \\
& -F 12 \\
& \rightarrow F 02 \\
& \rightarrow F 20 \\
& \rightarrow F 03 \\
& -F 32 \\
& \rightarrow F 04 \\
& -F 42
\end{aligned}
$$
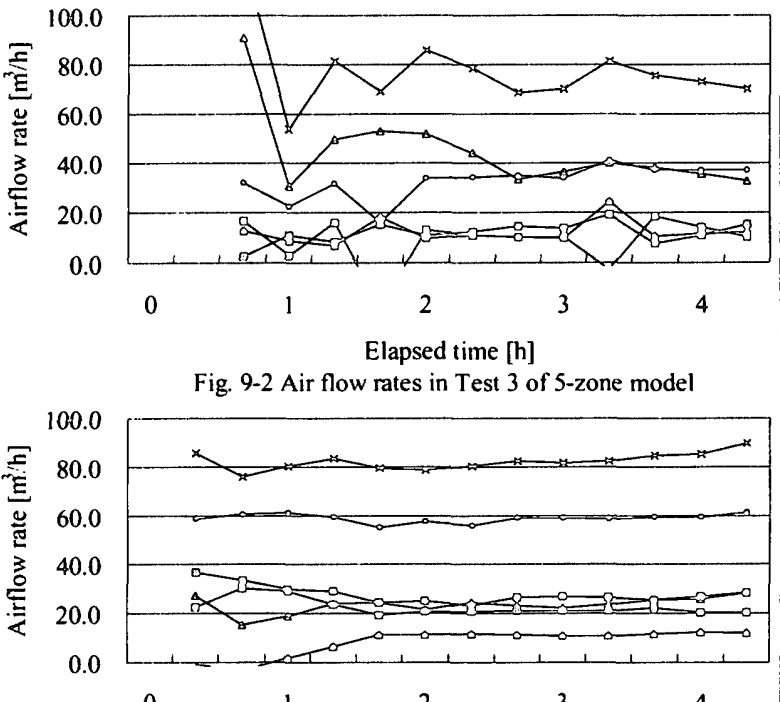

$-F 01$
$-F 15$
$-F 02$
$-F 20$
$-F 52$
$-F 03$
$-F 35$
$-F 04$
$-F 54$

Elapsed time [h]

Fig. 9-2 Air flow rates in Test 3 of 5-zone model

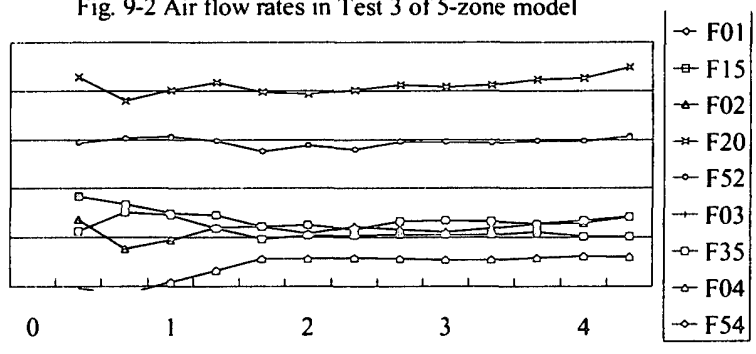

Elapsed time $[\mathrm{h}]$

Fig. 10-2 Air flow rates in Test 4 of 5-zone model
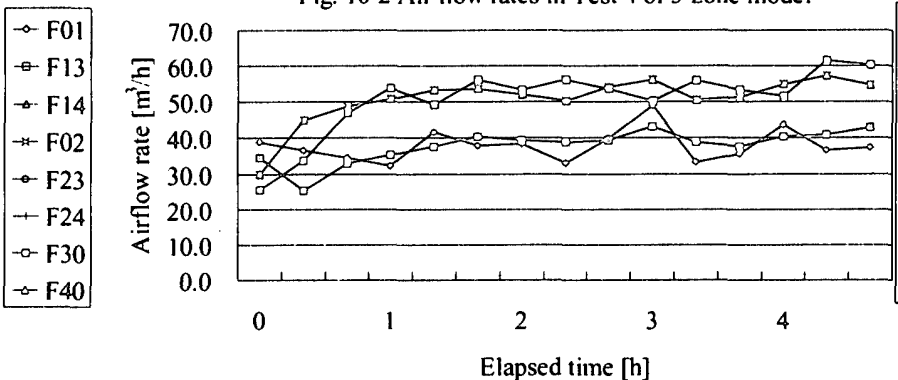

$-F 01$
$-F 15$
$-F 02$
$-F 25$
$-F 30$
$-F 53$
$-F 40$
$-F 54$

Fig. 11-2 Air flow rates in Test 5 of 5-zone model
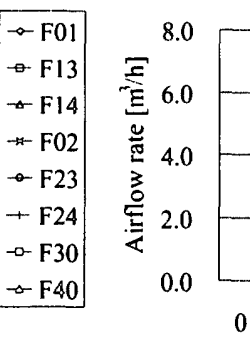

-

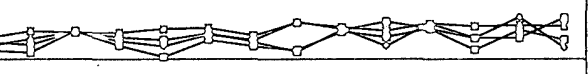

Elapsed time [h]

Fig. 12-2 Airflow rates in Test 6 of 5-zone model 
59.7

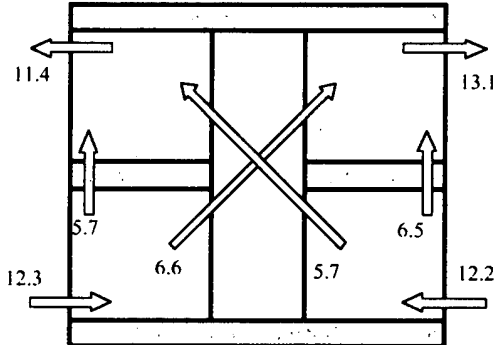

Test 1

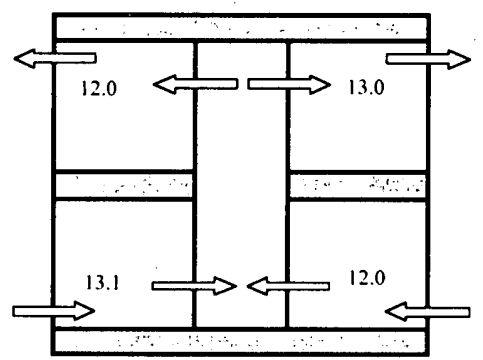

12.7

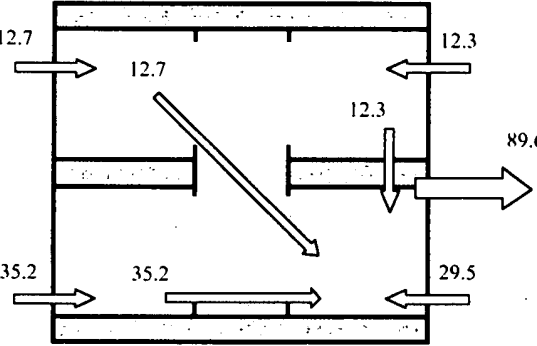

Test 4

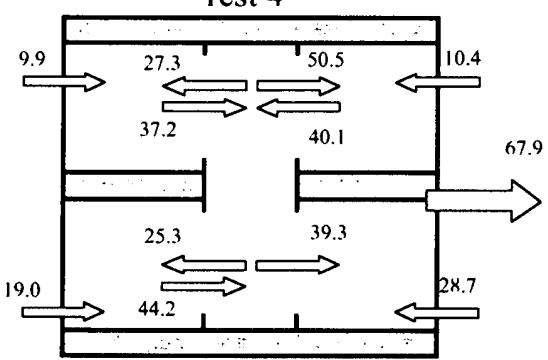

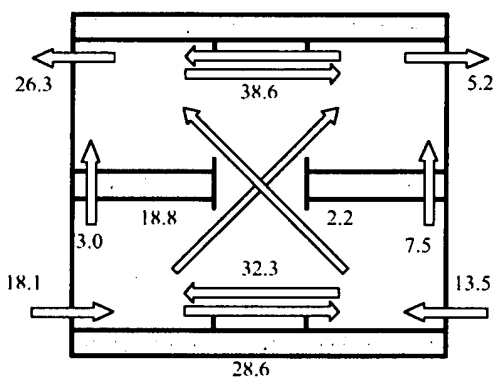

Test 2
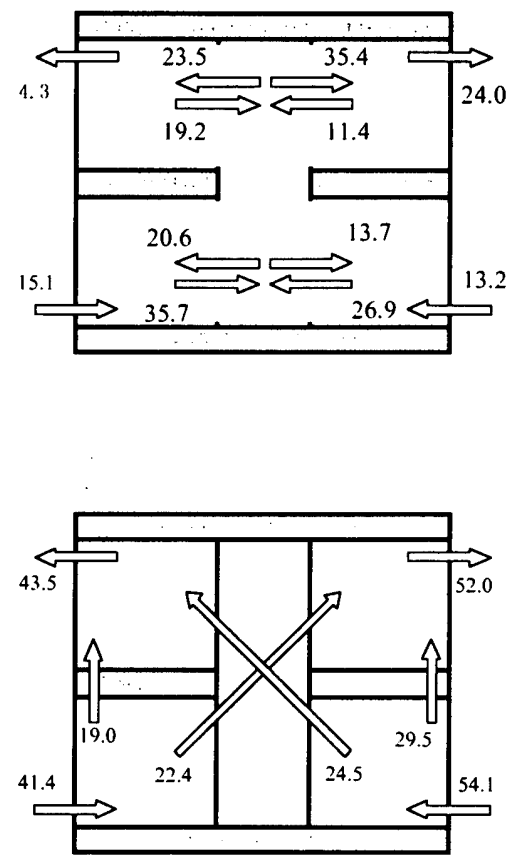

Test 5

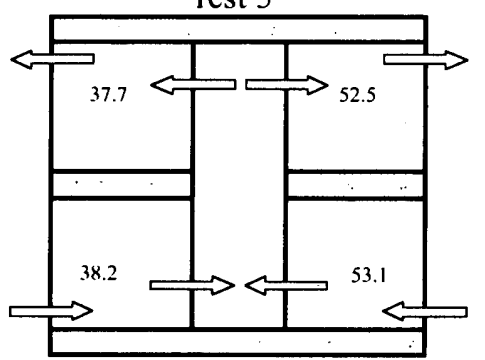

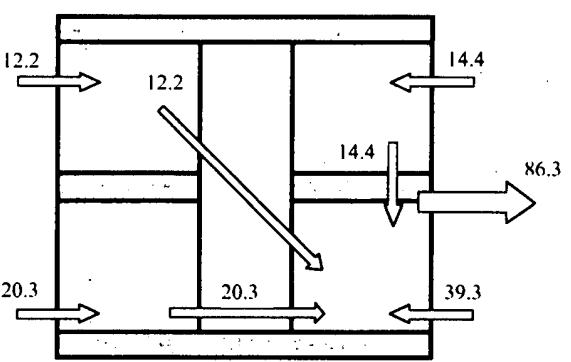

Test 3

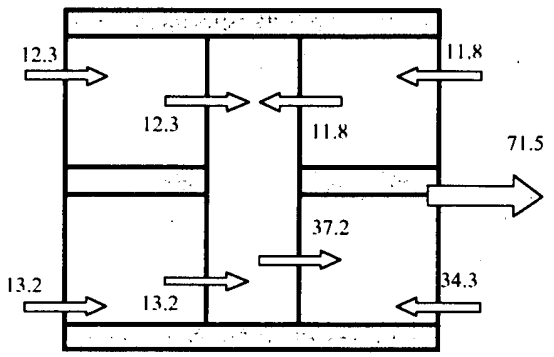

Test 6

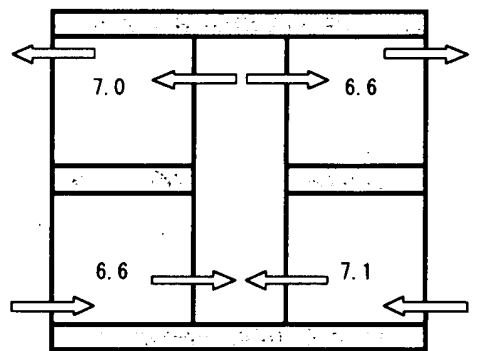

Fig. 13 Calculated results of airflow rates $\left(\mathrm{m}^{3} / \mathrm{h}\right.$, the upper row : 4-zone model, the lower row : 5-zone model)

定する。時間の経過と共にガス濃度むらが緩和されて, 設定値に 達する。(3)相当開口面積を $5\left[\mathrm{~cm}^{2} / \mathrm{m}^{2}\right]$ に設定し, 換気量が更に增大 すると [Test 5], 穩やかに拡散する現象よりも空気隗が入れ替わ る様な混合現象が優勢になり，設定值に達する時間は短縮される が，一部に未拡散領域が残ったような場合には，換気量は低めに 算定される。(4)機械換気になると Test 3，4]，混合現象が促進 され，多点サンプリングは瞬時一様に近いガス濃度を捉えている， 等々が考えられる。

室間換気量の算定結果が設定值に近づいてくる 3 時間経過後の 1 時間平均値を Fig. 13 に示寸。実測外気侵入量や排気量と設定值 をTable 2に示す。その実测外気侵入量や排気量と設定值の相関 をFig. 14 に示す。設定値を基準にして精度を検証すると，多種卜 レーサーガス法による測定結果は，概ねシリンダー通過風量 20〜 $30 \%$ 範囲内で得られている。シリンダーの通過風量を基に， 2
つのモデルを比較すると，両者とも換気量が小さめに算定された。 多種トレーサーガス法による実測全体で見ると， 5 室モデルのR² 值が高く，シリンダー風量との相関（傾き）で見ると，4室モデ ルの方が好結果となった。本実測のみで結論を出すのは早計であ るが, 多種トレーサーガス法が室数に応じたトレーサーガス数を 必ずしも必要としないことや，実体容積のない仮想の換気連絡路 を想定したモデリングも一つの有効な手段であることが確認され た。

\section{5. おわりに}

換気量既知の実大試験住宅（シリンダーハウス）を用いた多種 トレーサーガス法の検証結果から，次の知見を得た。

（1）自然換気 : 4 種, 機械換気 : 2 種, 計 6 種の検証実験から, 多 種トレーサーガス法による. 4 室モデルと 5 室モデルの換気量の算 
定結果は，概ねシリンダー通過風量の $20 \sim 30 \%$ の範囲内にある ことが確認された。これは既報の 2 室モデルや 3 室モデルにおけ る検証結果と比べてもそれ程大きな開きはない5)，6。

(2) 機械換気は、放出直後から設定条件に亟めて近い值を得るこ とが出来るが, 温度差換気は換気量が増加すると, 設定値に達す るに必要とする時間が増大し，算定結果も低めに現れる。この原 因として，円滑な拡散混合を阻む温度差換気特有の旅度むらが考 えられ，多種トレーサガス法を用いて自然換気量を実測する際の、 瞬時一様拡散とその必要条件である室平均搌度の測定に向けた工 夫は, 引き続き今後の要検討課題である。

(3) 多数室の室間換気量の測定に際し, 室総数未満のトレーサー ガス数であっても，実体容䅱なしの仮想の換気連絡路を想定する 等のモデリングをエ夫することによって，多種トレーサーガス法 を用いた限定ターゲットの室間換気量の測定は可能である。

本論文は 5th CANADA/JAPAN Housing Workshop 報告 ${ }^{10)}$ 基に新しい知見を加えて整理したものである。

铭碎: 本共同研究は建築研究所第 5 研究部・坊垣和明博士の助言 から出発している。測定に際し（財）ベーターリビング筑波建築 試験センターの協力, 換気量既知空間による多種トレーサーガス 法の検証に際しカナダ国立研究所 C.Y. Shaw 博士の示唆, 及び平 成 11 年度文部省科学研究補助金 B2 (10450208)の研究援助があつ た。記して感謝する。

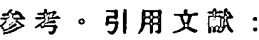

1）荒谷登・斎藤純司: 2 種ガス $\left(\mathrm{CO}_{2}, \mathrm{C}_{3} \mathrm{H}_{8}\right)$ 連続発生による多数 室建物の換気量測定法について, 日本建筑学会大会学術講演 梗概集・環境, pp. 307-308, 昭和 47 年 10 月

2) H. Honma:Ventilation of Dwellings and Its Disturbances(1975), Fabio Grafiska, Stockholm

3) S.J. I'Anson, C. Irwin, A.T. Howarth:Airflow Measurement UsingThreeTracerGases, Building and Environment Vol.17, No.4, pp.245-252, 1982

4) M. Enai, C.Y. Shaw, J.T. Reardon, R.J. Magee: Multiple Tracer Gas Techniques for Measuring Interzonal Airflows for Three Interconnected Spaces, ASHRAE Trans. AT-90-5-2(3369), 1990.1

5) M. Enai, N. Aratani, C.Y. Shaw, J.T. Reardon: Differential and Integral Method for Computing Interzonal Airflows Using Multiple Tracer Gases, Proceedings of ISRACVE,ASHRAE (90363) pp.357-362, 1993.7

6）絵内正道・荒谷登・C.Y. Shaw: 多種トレーサガス法に基づ く多数室換気量の算定 part-1, 空気調和・衛生工学会論文集 . No.51, pp.15-17, 1993.2

7）奥山博康・濢地孝男・瀬戸裕直・大西由哲：トレーサーガス を用いた換気性状把握手法の検証と改良その1, 日本建築学 会大会学術講演梗概集・環境,pp. 641-642, 1997.9

8）絵内正道・C.Y. Shaw, J.T. Reardon・荒谷登・梶井浩史・ 福自史幸：多種トレーサガス法に基づく多数室換気量の算定 part-2, 空気調和・衛生工学会論文集. No.72, pp.117$127,1999.1$

9）山田裕巳・林基哉：多室への新鮮空気配分を考愿したパッシ ブ換気方式の検討(その4), 日本建築学会大会学術謘演梗概集 (関賁) $・ D 2, p p .615-616,1997.9$

10）絵内正道・島田潔・福島史幸・澤地孝男・瀬戸裕直：換気量 既知の試験住宅を用いた多種ガス法の検定，5th CANADA/ JAPAN Housing Workshop, pp.400-407,1999.8
Table $2 \mathbb{R}$ esults obtained by pressure difference and those obtained by the tracer gas technique $\left(\mathrm{m}^{3} / \mathrm{h}\right)$

\begin{tabular}{|c|c|c|c|c|c|c|c|}
\hline Test & Method & & LV & DK & BS & $\mathrm{BN}$ & $\begin{array}{l}\text { Exhaust } \\
\text { airflow } \\
\text { tates }\end{array}$ \\
\hline I & $\begin{array}{l}\text { Pressure difference } \\
\text { Tracer gas technique }\end{array}$ & $\begin{array}{l}\text { (4-zone) } \\
\text { (5-zone) }\end{array}$ & $\begin{array}{l}-15.0 \\
-12.3 \\
-13.1 \\
\end{array}$ & $\begin{array}{l}-14.7 \\
-12.2 \\
-12.0\end{array}$ & $\begin{array}{l}14.4 \\
11.4 \\
12.0 \\
\end{array}$ & $\begin{array}{l}14.7 \\
13.1 \\
13.0 \\
\end{array}$ & \\
\hline 2 & $\begin{array}{l}\text { Pressure difference } \\
\text { Tracer gas technique }\end{array}$ & $\begin{array}{l}\text { (4-zone) } \\
\text { (5-zone) }\end{array}$ & $\begin{array}{r}-14.8 \\
-18.1 \\
-15.1 \\
\end{array}$ & $\begin{array}{r}-14.6 \\
-13.5 \\
-13.2 \\
\end{array}$ & $\begin{array}{r}14.6 \\
26.3 \\
4.3 \\
\end{array}$ & $\begin{array}{r}14.7 \\
5.2 \\
24.0 \\
\end{array}$ & \\
\hline 3 & $\begin{array}{l}\text { Pressure difference } \\
\text { Tracer gas technique }\end{array}$ & $\begin{array}{l}\text { (4-zone) } \\
\text { (5-zone) } \\
\end{array}$ & $\begin{array}{r}-25.7 \\
-20.3 \\
-13.2 \\
\end{array}$ & $\begin{array}{l}-26.5 \\
-39.3 \\
-34.3 \\
\end{array}$ & $\begin{array}{r}-14.7 \\
-12.2 \\
-12.3 \\
\end{array}$ & $\begin{array}{r}-14.5 \\
-14.4 \\
-11.8 \\
\end{array}$ & $\begin{array}{l}81.4 \\
86.3 \\
71.5 \\
\end{array}$ \\
\hline 4 & $\begin{array}{l}\text { Pressure difference } \\
\text { Tracer gas technique }\end{array}$ & $\begin{array}{l}\text { (4-zone) } \\
\text { (5-zone) }\end{array}$ & $\begin{array}{r}-25.7 \\
-35.2 \\
-19.0 \\
\end{array}$ & $\begin{array}{l}-26.5 \\
-29.5 \\
-28.7 \\
\end{array}$ & $\begin{array}{r}-14.6 \\
-12.7 \\
-9.9 \\
\end{array}$ & $\begin{array}{r}-14.4 \\
-12.3 \\
-10.4 \\
\end{array}$ & $\begin{array}{l}81.2 \\
89.6 \\
67.9 \\
\end{array}$ \\
\hline 5 & $\begin{array}{l}\text { Pressure difference } \\
\text { Tracer gas technique }\end{array}$ & $\begin{array}{l}\text { (4tone) } \\
\text { (5-zone) }\end{array}$ & $\begin{array}{l}-64.8 \\
-41.4 \\
-38.2 \\
\end{array}$ & $\begin{array}{r}-64.8 \\
-54.1 \\
-53.1 \\
\end{array}$ & $\begin{array}{r}63.2 \\
43.5 \\
37.7 \\
\end{array}$ & $\begin{array}{l}63.6 \\
52.0 \\
52.5 \\
\end{array}$ & \\
\hline 6 & $\begin{array}{l}\text { Pressure difference } \\
\text { Tracer gas technique }\end{array}$ & $\begin{array}{l}\text { (4-zone) } \\
\text { (5-zone) }\end{array}$ & $\begin{array}{l}-9.2 \\
-7.1 \\
-6.6\end{array}$ & $\begin{array}{l}-8.8 \\
-7.0 \\
-7.1 \\
\end{array}$ & $\begin{array}{l}8.0 \\
6.7 \\
7.0\end{array}$ & $\begin{array}{l}8.5 \\
7.3 \\
6.6 \\
\end{array}$ & \\
\hline
\end{tabular}

$\underset{\xi}{\xi}$
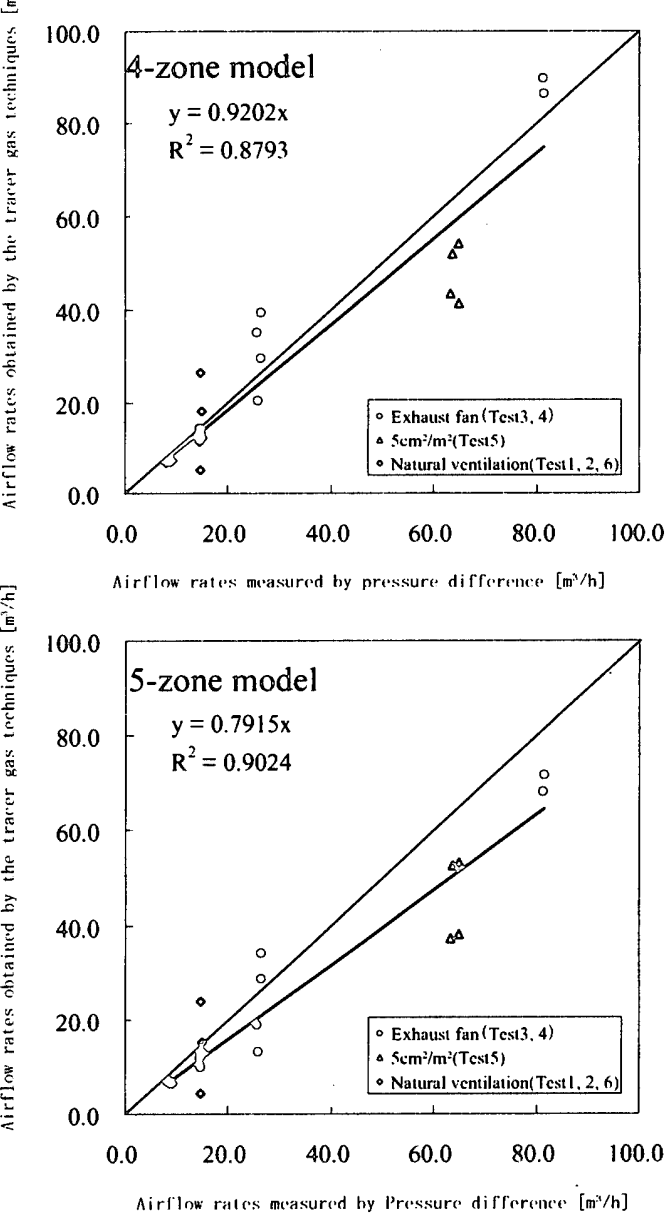

Fig. 14 Correlation between airflow rates measured by differential pressure and those obtained by tracer gas techniques

11）澤地孝男・坊垣和明・大澤元毅・瀬戸裕直・大西䇣樹・谷口 佳記 : 住宅の換気システムに関する実験的研究 その 2 実験 施設 (シリンダーハウス)の特性, 空気調和・衛生工学会学術 䛬演会講演論文集 (熊本)，Ｉ， pp.649-652，1994

(1999年11月26日原稿受理, 2000 年 6 月 22 日採用決定） 